\title{
CORRIGENDUM
}

\section{Allogeneic haematopoietic stem cell transplant in patients with lower risk myelodysplastic syndrome: a retrospective analysis on behalf of the Chronic Malignancy Working Party of the EBMT}

M Robin, R Porcher, W Zinke-Cerwenka, A van Biezen, L Volin, G Mufti, C Craddock, J Finke, C Richard, J Passweg, A Peniket, J Maertens, G Sucak, T Gedde-Dahl, A Vitek, A Nagler, D Blaise, D Beelen, N Maillard, R Schwerdtfeger, T de Witte and N Kroger

Bone Marrow Transplantation (2017) 52, 1081; doi:10.1038/bmt.2017.86

Correction to: Bone Marrow Transplantation (2016) 52, 209-215; doi:10.1038/bmt.2016.266; published online 7 November 2016

Since the publication of this article, it has been noted that an acknowledgement was inadvertently not included in the paper.

The acknowledgement is now given here:
AP acknowledges funding from The Haematology and Stem Cell Theme of the Oxford Biomedical Research Centre (BRC).

The authors would like to apologise for this error. 